\title{
The Europeanisation of Spanish Administrative Law through the Principle of Legitimate Expectations
}

\author{
Luis Arroyo Jiménez* \\ Professor of Administrative Law at University of Castilla-La Mancha \\ Gabriel Doménech Pascual \\ Professor of Administrative Law at University of Valencia
}

\begin{abstract}
This article describes the Europeanisation of Spanish administrative law as a result of the influence of the EU law general principle of legitimate expectations. It examines, firstly, whether the formal incorporation of the principle of legitimate expectations into national legislation and case law has modified the substance of the latter, and if so, secondly, whether this has led to a weaker or a more robust protection of the legal status quo. To carry out that examination, the article considers the influence of the principle of legitimate expectations in two different areas: in individual administrative decision-making, and in legislative and administrative rulemaking. Our conclusion is that the Europeanisation of Spanish administrative law through the principle of legitimate expectations has been variable and ambiguous.
\end{abstract}

\section{Introduction}

This article explores the Europeanisation of Spanish administrative law, in particular through the influence of the principle of legitimate expectations, a 'general principle' of EU law. Europeanisation is a process of transformation of national principles, rules and doctrines as a consequence of European - in this article mainly, EU law. Europeanisation can be seen as emerging for two different reasons. Firstly, it often arises from the duty to adopt or adapt domestic administrative law to be in line with EU legislation as it evolves, and to align with or comply with case law of the Court of Justice, in particular areas of administration. Secondly, through the application of general principles of EU law. General principles can lead to a broader and deeper influence in domestic legal systems because they are not restricted to particular areas of law or to a specific instrument of administrative action: they have horizontal

DOI 10.7590/187479820X15930701852256 1874-7981 2020 Review of European Administrative Law

This paper has been written with the support of a grant of the Spanish National Research Plan (PGC2018-101476-B-Ioo). 
and cross-sectional effects, and often apply abstractly, as part of a doctrine, and through administrative law instruments that have a structural nature.

Both the legal value and content of any given EU law general principle is the same in all the EU Member States. This is a consequence of the requirement of uniformity in EU law. Nevertheless, in practice, Europeanisation occurs rather differently in each of the Member States; The same general principle of EU law can actually influence various national legal orders differently, not only in terms of the extent of transformation that it causes, but also in view of the pieces or building blocks of the domestic legal order that will possibly be affected. Those differences are not directly due to the principle; they ultimately depend on the particular nature of the national legal order which applies the principle. A plausible working hypothesis might be that the same general principle of EU law may produce different consequences in one Member State compared to another depending on the following criteria: (i) the degree to which domestic administrative law is constrained by domestic constitutional law; (ii) whether administrative law is subject to a more or less formalistic legislative codification; (iii) how rigid or flexible both administrative law rule-making and judicial precedent are; and (iv) how open and cosmopolitan the administrative law system and its legal culture are.

This article is not intended to discuss the principle of legitimate expectations protection as a matter of EU law, ${ }^{1}$ nor it is aimed at making a contribution in this latter field. Rather, we will describe the influence that EU law has had in Spanish administrative law. Taking this influence as a case-study is particularly useful because it allows more than just an observation of how it has unfolded in that Member State, it also makes possible to verify the said hypothesis more broadly, and ultimately to compare this particular experience with that of other Member States' legal orders. Turning to the structure, this article aims to answer two specific research questions. The first is whether the formal incorporation of the principle of legitimate expectations into Spanish administrative law has modified the substance of the latter. The second, if the answer to the latter is yes, is whether this has led to a weaker or to a more robust protection of the stability of the legal status quo. In order to address these two questions, this paper will assess the impact of the EU law principle of legitimate expectations in two different areas: when expectations are frustrated by individual adminis-

\footnotetext{
See R Thomas, Legitimate Expectations and Proportionality in Administrative Law (Hart 2000) (Thomas); S Schønberg, Legitimate Expectations in Administrative Law (OUP 2000) (Schønberg); H-J Blanke, Vertrauenschutz in deutschen und europäischen Verwaltungsrecht (Mohr Siebeck 2001); T Tridimas, The General Principles of EU Law (OUP 2006); X Groussot, General Principles of Community Law (Europa Law Publishing 2006), 202-214; D Dero-Bugni, 'Les principes de sécurité juridique et de confiance légitime’, in J-B Auby and JD de la Rochère (eds), Traite du droit administrative européen (Bruylant 2014), 651-670.
} 
trative decisions (section 3), and when they are frustrated by legislative or administrative rules (section 4). Then the article will focus on a specific development in Spanish (Supreme Court) case law in the area of State liability for damages caused by Parliamentary laws, where the EU law principle of legitimate expectations has allegedly played an important role (section 5). Before doing so, there must first be a preliminary discussion of how the principle was received in national administrative law (section 2).

\section{Incorporation of the principle of legitimate expectations in Spain}

Article 9.3 of the Spanish Constitution lists the principle of legal certainty among a number of other principles, which have always been connected to the rule of law:

'The Constitution guarantees the principle of legality, the hierarchy of legal provisions, the publicity of legal statutes, the principle of legal certainty and the non-retroactivity of both non-favourable punitive provisions and provisions restrictive of individual rights, the rule of law, the accountability of public authorities, and the prohibition of arbitrary action of public authorities'.

Nevertheless, there has never been any expression of legal certainty in the form of the legal protection of legitimate expectations in any statutory instrument or judgment. Not even the term 'legitimate expectations' itself, or others more or less equivalent to it, such as 'legitimate confidence', or 'legitimate trust' have appeared in that context.

The first time it was mentioned was in a judgment of the Supreme Court of 1989: a private school applied for a subsidy which was refused by the administrative authority in an administrative decision. However, it had in fact granted that subsidy to the same applicant in the previous period of the school year, which had created expectations for the school, and the rejection was therefore held to frustrate those expectations:

'With the rejection of the subsidy application the 'fides' or trust of the applicant was broken in a case in which the latter was performing a burdensome activity of public interest under the expectation that the new subsidy was going to be granted just like the previous one [...] It is therefore a requirement of good faith to believe that once a subsidy for the first period of the school year has been granted, the subsidy for the next periods of the same school year will also be granted, provided that circumstances remain the same'. 
Ultimately, the Supreme Court quashed the administrative decision and declared the right of the private school to receive the subsidy for the remainder of the school year. This ruling seems to ground the protection of the legal status quo on the notion of good faith - which had been traditionally proclaimed as a general principle of law in Article 6.1 of the Civil Code. It also seems to be based on the principle of nemoauditur propriam turpitudinem allegans - which has always been a topos used very widely in legal reasoning. However, there was no reference or basis on the constitutional principle of legal certainty. The expression 'legitimate expectations' is not even used by the Court. Nevertheless, the underlying principle is that an expectation which the applicant could reasonably rely on had been created by the previous administrative decision, and that it was unlawful for the same authority to frustrate those expectations.

This ruling was paid immediate attention in academic literature, and various case notes pointed to the German public law principle of Vertrauensschutz as the principle of law that was being applied in this ruling. ${ }^{3}$ Very shortly after, the Supreme Court handed down two new judgments that helped to consolidate the principle, as well as to clarify its legal context. ${ }^{4}$ One of them, also concerning an administrative decision rejecting a subsidy that a private school had applied for, said that:

'In the conflict between the principles of legality of administrative action and of legal certainty, the latter prevails by virtue of the protection of legitimate expectations, which has been implicitly proclaimed by this Court in its Judgment of 28 February 1989 (RJ 1989/1458). While having its origins in the law of the Federal Republic of Germany, it has also been recognised in the case law of the Court of Justice of the European Communities, of which Spain is a Member State. The principle does not depend on the mere psychological belief of the beneficiary, but rather requires the expectations to be based on external signs coming from the Administration that are conclusive enough to reasonably induce him to rely on the legality of the administrative action [and that the administrative act] causes damage to the beneficiary due to the investments that he previously made'. ${ }^{5}$

2 Judgment of the Spanish Supreme Court (Administrative Law Chamber) of 28 February 1989 (RJ 1989/1458), para 2.

3 F Marín Riaño, 'La recepción del principio de la confianza legítima en la jurisprudencia del Tribunal Supremo’ (1989) 2 La Ley 605.

4 Judgments of the Spanish Supreme Court (Administrative Law Chamber) of 26 January 1990 (RJ 1990/598), and of 1 February 1990 (RJ 1990/1258). J Quesada Lumbreras, 'Tres décadas de protección jurisprudencial de la confianza legítima’ (2010) 146 Revista Española de Derecho Administrativo 417 .

$5 \quad$ RJ 1990/1258 (n 4), para 2. 
Interestingly enough, the Supreme Court acknowledges the structure of the 'legal transplant' that is grounded in the authority of EC law, which can be traced back to German public law. As a matter of fact, subsequent academic scholarship has resorted directly to the latter, ${ }^{6}$ at least as much as it has to the case law of the Court of Justice, ${ }^{7}$ in seeking clarification of the factual conditions of application and the legal effects of this principle. It is uncertain which of these two sources was more influential in the development of the Supreme Court's doctrine on legitimate expectations in the three subsequent decades. In other words, while formally the legal influence has come through the case law of the Court of Justice, from a substantive perspective it is not at all clear whether we have witnessed a more horizontal (from a neighbouring Member State's legal order) than vertical (from the EU legal order) legal transplant. Indeed, as it will be demonstrated next, the respective importance of these sources might well vary depending on which dimension of legitimate expectations' protection is at stake.

The torch for the development of the principle was then taken by the Spanish Parliament. In 1999 it amended the 1992 Administrative Procedure Act, ${ }^{8}$ so that the new wording of Article 3 established that administrative bodies:

'shall comply with the principles of good faith and legitimate expectations'.

$6 \quad$ F Castillo Blanco, La protección de la confianza en el Derecho administrativo (Marcial Pons 1999) (Castillo Blanco); J García Luengo, El principio de protección de la confianza en el Derecho administrativo (Marcial Pons 2002) (García Luengo); S Díez Sastre, El precedente administrativo (Marcial Pons) 2008 (Díez Sastre); J García Luengo, 'El principio de protección de la confianza' in JA Santamaría Pastor (ed), Los principios jurídicos del Derecho administrativo (La Ley 2010), 1167-1205; T Müller, Die Europäiesierung der Verwaltungsverfahrensgesetze in Deutschland und Spanien (Mohr Siebeck 2019), 44.

7 See R García Macho, 'Contenido y límites del principio de protección de la confianza legítima: estudio sistemático de la jurisprudencia del Tribunal de Justicia’ (1987) 57 Revista Española de Derecho Administrativo 557, 557-571; S Muñoz Machado, 'Regulación y confianza legítima' (2016) 200 Revista de Administración Pública 141 (Muñoz Machado); R Alonso García, 'Treinta años de ius publicum commune en España' (2016) 200 Revista de Administración Pública 341.

8 Act No. 30/1992, of 26 November 1992, on Public Administration and Common Administrative Procedure (Official Journal No. 285, of 27 November 1992, 40300-40319) (Act No. 30/1992), as amended by Act No. 4/1999, of 13 January 1999 (Official Journal No. 12, of 14 January 1999 , 1739-1755) (Act No. 4/1999). 
The preamble of the 1999 amendment declared that it incorporates into the statute:

'two new general principles of administrative action that stem from legal security. On the one hand, the principle of good faith ... On the other, the principle of legitimate expectations, which protects citizens against their arbitrary frustration by administrative authorities. The second one is well established in European administrative procedural law, as well as in national administrative law case law'. ${ }^{9}$

Since 1999, therefore, protection of legitimate expectations has been proclaimed as a general or horizontal principle of law which applies to statutes, as well as administrative rules and individual administrative decisions. The Administrative Procedure Act does not, however, define the conditions for the principle to apply, nor what remedies would apply in the event of a violation of the principle. In particular, it doesn't specify when the latter could lead to an action for annulment and/or to a claim for damages - i.e., when the principle grants substantive or compensatory protection. ${ }^{10}$ Some authors consider that compensation should be the single effect of the violation of the principle of protection of legitimate expectations, especially when it collides with the principle of legality. In turn, the mentioned rulings of the Supreme Court invalidate otherwise lawful administrative decisions by virtue of the principle of legitimate expectations. In these cases, the individual may additionally have a right to be compensated for damages caused by an unlawful administrative decision, ${ }^{12}$ and compensation would thus not function as a substitute for annulment, but as an additional legal consequence arising from the principle of legitimate expectations. This implies that, under this case-law, the latter grants both substantive and compensatory protection. Moreover, some authors argue that the principle can also prevent the public administration from eliminating an illegal situation favorable to an individual, and even force it to maintain contra legem an illegal favorable act, either on a general basis, ${ }^{13}$ or exceptionally. ${ }^{14}$ German jurisprudence on the conservation of favorable illegal administrative acts, such as social security benefits, ${ }^{15}$ seems to have exerted more influence on Spanish case law and

\footnotetext{
Act No. 4/1999 (n 8), Preamble, Section II.

See Schønberg (n 1) passim.

L Medina Alcoz, 'Confianza legítima y responsabilidad patrimonial' (2006) 130 Revista Española de Derecho Administrativo 290 (Medina Alcoz). 
academic doctrine than the Court of Justice, at least in regards to the question of remedies. ${ }^{16}$

This is the story of the formal or apparent incorporation of the principle into the domestic legal order. Nevertheless, long before 1989, Spanish public law had already dealt with the whole set of problems typically connected to the principle of legitimate expectations, such as the withdrawal of administrative acts, self-limitation of administrative authorities, and retroactivity. As a matter of fact, within the different layers of Spanish public law, a thick and refined network of solutions to those problems could be found. One of the sources was Article 9.3 of the 1978 Constitution, which, along with the principle of legal certainty, also stated the non-retroactivity of both non-favourable punitive provisions and provisions restrictive of individual rights. ${ }^{17}$ As we will see later, the Spanish Constitutional Court initially reviewed legislation that had retroactive effect using a formalistic approach, by simply trying to determine the meaning of the terms 'provisions', 'non-retroactivity', and 'restrictive of individual rights'. On another level, the 1958 Administrative Procedure Act already contained a detailed regulation of what would occur in the event of withdrawal of both adverse and favourable individual administrative decisions. ${ }^{18}$ The principle of legal certainty worked through this particular set of rules, and the courts did not use the constitutional principle of legal certainty in order to qualify them. ${ }^{19}$ Finally, despite lacking specific regulation by statute, the case law of administrative law courts had dealt with the typical forms of administrative self-limitation, such as administrative precedents, ${ }^{20}$ and answers given by administrative authorities to consultations made by individuals or firms - which were subject to well-established case law, especially in the field of private-project development. ${ }^{21}$ In view of this situation, it makes sense to assess whether the latter has made an actual difference in Spanish administrative law, and, if so, whether it

16 Díez Sastre (n 6), 401.

17 See M Azpitarte Sánchez, Cambiar el pasado (Tecnos 2008); M Vaquer Caballería, La eficacia territorial y temporal de las normas (Tirant lo Blanch 2010).

18 Act of 17 July 1958, on Administrative Procedure (Official Journal No. 171, of 18 July 1958, 12751287) (Act of 17 July 1958), arts 109-112. They were replaced, first, by Act No. 30/1992 (n 8), arts 102-106, and later by Act No. 39/2015, of 1 October 2015, on Common Administrative Procedure (Official Journal No. 236, of 2 October 2015, 89343-89410) (Act No. 39/2015), arts 106-111.

19 For a view of general administrative law statutes as an expression of legislative balancing among competing constitutional principles, where the latter operate through the former, see F Wollenschläger, 'Verfassung im Allgemeinem Verwaltungsrecht: Bedeutungsverlust durch Europäisierung und Emanzipation?’ (2016) 75 Veröffentlichungen der Vereinigung der Deutschen Staatsrechtslehrer 184, 199-200; and L Arroyo Jiménez, 'Derecho administrativo y Constitución Española’ (2019) 209 Revista de Administración Pública 155 (Arroyo Jiménez).

20 LM Díez-Picazo, 'La doctrina del precedente administrativo' (1982) 98 Revista de Administración Pública 7, 7-46; Díez Sastre (n 6), 226-238.

21 Díez Sastre (n 6), 381-382. 
has led to a higher or lower degree of legal protection of legitimate expectations generated by previous decisions of public authorities.

\section{Legitimate expectations and individual administrative decisions}

Legitimate expectations can be threatened and frustrated by individual decisions of administrative authorities. This can occur in two different types of cases, traditionally distinguished in general administrative law. First, rectification or withdrawal of previous administrative acts, and second, departure from individual representations and other previous non-binding administrative action (section 3.3). In turn, the first scenario can arise in different forms and thus various regimes may apply. Like other administrative legal orders, ${ }^{22}$ Spanish administrative law has different rules for rectification or withdrawal of previous individual decisions in view of two peculiar features of the latter, namely whether their content is favourable or adverse for their addressee, and whether they are lawful or unlawful. The implementation of these criteria give rise to different situations that are subject to a distinct legal regime: rectification and withdrawal of unlawful and favourable administrative acts (section 3.1), of lawful and favourable administrative acts (section 3.2), and of adverse - both lawful and unlawful - administrative acts. As the latter situation is not relevant in terms of protection of legitimate expectations, we will focus on the other. Finally, a part of this article will be devoted to a special case of unlawful and favourable acts: State aid that has to be recovered pursuant to a Commission Decision ruling that it was unlawfully granted (section 3.4).

\subsection{Rectification and withdrawal of unlawful and favourable administrative acts}

The first of these situations is rectification or withdrawal of unlawful and favorable acts. Under EU law, the principle of legitimate expectations qualifies the principle of legality, by restricting both administrative and judicial revocation of unlawful decisions. The Court of Justice has designed a balancing test which looks at the time that has elapsed between the initial act and its rectification or withdrawal, the discernibility of the illegality, the behaviour of the addressee, and the effective emergence of legitimate expectations. ${ }^{23}$

22 For a comprehensive review of eight EU Member States, see A Glaser, Die Entwicklung des Europäischen Verwaltungsrechts aus der Perspective der Handlungsgormenlehre (Mohr Siebeck 2013).

23 Cases 7/56 and 3-7/57, Algera $v$ Common Assembly [1957] ECR 39 (Algera v Common Assembly); Joined cases 42 and 49/59 SNUPAT v High Authority [1961] ECR 53; Case 14/61 Hoogovens $v$ High Authority [1962] ECR 253; Case C-14/181 Alpha Steel v Commission [1982] ECR 749; Case 
Conditions imposed on retroactive revocation are stricter than those on prospective revocation. If there is a breach of the principle, under EU law an annulment action can be brought, but compensation claims are not possible.

Spanish administrative law has had a specific regulation on revocation of unlawful and favourable acts - including administrative decisions with mixed or double effects ${ }^{24}$ - since the 1958 Administrative Procedure Act. At present it can be found in Articles 106 and 107 of the 2015 Administrative Procedure Act. The starting point in positive law shows that there is a sharp distinction between ordinary and extraordinary grounds of illegality. This is notably different to EU law, which provides for a common balancing test irrespective of the seriousness of the illegality, while only discernibility might be of relevance. ${ }^{25}$

In Spain, factual and legal errors that lead to the invalidity of an individual administrative decision belong, by default, to the first category (anulabilidad, or nulidad relativa). Legal certainty, and particularly legitimate expectations created by this first type of administrative decisions, are protected in a very robust manner: they cannot be revoked by the administrative authorities that made them. Instead, the authorities that adopted those acts have to challenge them before a court within a four-year period, thus seeking judicial review of their own decisions. ${ }^{26}$ In turn, individuals or firms affected or harmed by them have to lodge their actions of annulment within two months. ${ }^{27}$

Rectification or withdrawal may be ordered by an administrative authority only when there are particularly serious and manifest grounds of illegality (nulidad absoluta), that are specifically provided for by the law, such as violation of fundamental rights, manifest lack of competence, criminal offence, and so on. ${ }^{28}$ Furthermore, this may be decided only after implementing a very detailed and complex administrative procedure that requires a favourable opinion from an independent consultative body (Consejo de Estado) regarding the existence of those serious grounds of illegality. ${ }^{29}$ Finally, even if all these requirements are met, a favourable administrative act can only be modified or withdrawn within a reasonable period of time. ${ }^{30}$ The Supreme Court interprets this limita-

12/85 Consorzio Cooperative d'Abruzzo v Commission [1987] ECR 1005; Case C-90/95, P Henri de Compte $v$ European parliament [1997] ECRI-1999.

24 M Sánchez Morón, Derecho administrativo. Parte General (Tecnos 2016) (Sánchez Morón), 582.

25 P Craig, EU Administrative Law (3rd edn, OUP 2018) (Craig), 615-616.

26 Act No. 39/2015 (n 18), art 107.

27 Act No. 29/1998, of 13 July (Official Journal No. 167, of 14 July), art 46(1).

28 Act No. 39/2015 (n 18), art 47(1).

29 ibid art $106(1)$.

30 ibid art 110. 
tion according to the particular circumstances of the case and in a rather flexible manner, implementing it only when the authority revoked a previous decision after a very long period of time..$^{31}$

The principles of legal certainty and legitimate expectations do not only limit the cases when administrative acts can be rectified or withdrawn. Rather, they can also qualify the content and effects of the withdrawal decision, from two different perspectives. On the one hand, since $1958,{ }^{32}$ our different Administrative Procedure Acts have established that the power to withdraw may not be exercised when, in view of the circumstances at stake, «this would be contrary to equity, good faith, the right of individuals or the law». ${ }^{33}$ Courts often use this provision in order to decide not to order revocation - as has been said, for example, if a long period of time had passed. What they do not do is invoke it in order to qualify the annulment effects. Judicial annulments of administrative acts which are disputed on ordinary grounds of illegality always have mere prospective effect (ex nunc). Therefore, the legal effects of the decision between the enactment and the annulment of the act would be maintained. In turn, both judicial and administrative annulment of administrative acts incurring in serious and obvious grounds of illegality has retroactive effect (ex tunc), which means that there would no longer be any legal effects of the decision between the enactment and the annulment of the act. ${ }^{34}$

Some authors have argued that the said general provision can be construed as allowing the granting, if the circumstances of the case require legitimate expectations to be protected, of only prospective effects to the annulment of a favourable, unlawful administrative decision, even if it presents a particularly serious and manifest illegality. ${ }^{35}$ This would also be in line with the case law of the Court of Justice, which implements a balancing test that imposes more strict conditions for allowing retroactive revocation than for prospective revocation. ${ }^{36}$ Spanish courts, in turn, acknowledge a strict connection between nulidad absoluta and retroactivity. If it is found that the legal status quo created by the

31 Judgments of the Spanish Supreme Court (Administrative Law Chamber) of 23 October 2000 (RJ 2000/9001) - four years, of 30 September 2009 (RJ 2010/937) - 20 years; and of 19 February $2014(2014 / 1650)-10$ years.

32 Act of 17 July 1958 (n 18), art 112.

33 Act No. 39/2015 (n 18), art 110.

34 Judgments of the Spanish Supreme Court (Administrative Law Chamber) of 26 September 1988 (RJ 1988/7262); of 28 November 1989 (RJ 1989/8359); of 20 March 1990 (RJ 1990/2243); of March 1998 (RJ 1998/1885); of 2 March 2015 (RJ 2015/1782). See J García Luengo, La nulidad de pleno Derecho de los actos administrativos (Civitas 2002); T Cano Campos, 'El laberinto de la invalidez: algunas pistas para no perderse' (2017) 4 InDret 10.

35 Sánchez Morón (n 24), 584.

36 Craig (n 25), 618. 
administrative act must be maintained, the annulment will be rejected altogether. ${ }^{37}$ Therefore, that provision is implemented in an all-or-nothing manner: either declaring the act valid, if courts believe that legal certainty must prevail over the principle of legality, or annulling it with retroactive effect, if the opposite is true. It is uncertain whether this case law grants more or less protection to those who have legitimate expectations. What is apparent though is that it leads to an overly rigid and crude solution.

There is a second perspective on how legal certainty and legitimate expectations can qualify the effects of a revocation decision. Since the 1992 Administrative Procedure Act, ${ }^{38}$ if the circumstances of the case require it, the administrative authority may annul a favourable, unlawful decision that it had previously taken, while granting damages to its beneficiary. ${ }^{39}$ This is another important difference when compared to EU law, where legitimate expectations are protected vis-à-vis revocation exclusively by annulment actions. Nevertheless, in order to decide when a claim for damages should be upheld, Spanish courts apply three criteria that have been traditionally connected to the principle of legitimate expectations in EU law and other national administrative legal orders. First, they assess how serious and manifest the illegality was, because if it was readily apparent that the previous administrative decision was illegal, there are no legitimate expectations to protect at all:

'The fact that the illegality [of the subsidy] was so obvious, as well as the lack of any previous administrative procedure, force us to reject that the administrative withdrawal of the granting decision may have violated the principles of good faith or legitimate expectations'. ${ }^{40}$

This criterion makes it very difficult to grant damages in cases concerning administrative decisions that withdraw previous favourable acts because, as has been said, for that to be possible, the latter have to show there is a particularly serious and obvious illegality. Therefore, damages provided for in Article 110.4 of Act No. 39/2015 of 1 October 2015 will normally be granted by a court in a judicial review procedure, and not by an administrative authority in the context of a revocation procedure. The second criterion relates to the role played by the beneficiary of the act in its illegality: if the factual or legal error was provoked by the beneficiary, she will not be entitled to make a damages claim. There are

37 Judgments of the Spanish Supreme Court (Administrative Law Chamber) of 4 May 2017 (RJ 2017/2415); of 11 January 2017 (RJ 2017/42); and of 22 May 2019 (RJ 2019/2090).

38 Act No. 30/1992 (n 8), art 102(4).

39 Act No. 39/2015 (n 18), art 110(4).

40 RJ 2017/2415 (n 37), para 9. 
simply no legitimate expectations to protect in this case..$^{41}$ Finally, for compensation to be granted, the beneficiary must have actually made an investment in the belief that the legal status quo created by the administrative act would be mantained. As a matter of fact, under the principle of legitimate expectations, the damages that have to be paid are only damages directly linked with those investments and expenses, as well as with the loss of profit related to business opportunities that were rejected because the beneficiary trusted in the legality of the previous decision - often called 'the negative interest'. ${ }^{42}$

\subsection{Rectification and withdrawal of lawful and favourable administrative acts}

The degree of protection of legitimate expectations is greater in this scenario because, as the previous administrative act is lawful, the loss of legitimate expectations is not justified by the principle of legality. There are four different categories of cases to be distinguished under Spanish law.

The principle of legitimate expectations does not provide for annulment actions, nor for damages, in the first of them: when the favourable act is revoked by the administrative authority because the rights-holder no longer complies with the legal conditions. ${ }^{43}$ The revocation of the right would be mandatory if compliance with those conditions was required by the law, and merely facultative if they were imposed in the administrative act on the basis of a discretionary power. The rights-holder will not have a right to be compensated in any of these cases, because she could not expect to continue to exercise the right without complying with the conditions established by the law or the decision granting it. ${ }^{44}$ The same happens in the second category of cases: when the right was granted under the condition of possible revocation, something that can only happen if the conferral of the right was itself a discretional prerogative. ${ }^{45}$ Again, the rights-holder cannot argue that she reasonably relied on the stability of the

$41 \quad$ Craig (n 25), 613-618.

42 The concept was developed by R von Jehring, 'Culpa in contrahendo, oder Schadensersatz bei nichtigen oder nicht zur Perfection gelangten Verträgen' (1861) 4 Jahrbücher für die Dogmatik des heutigen römischen und deutschen Privatrechts 1; see also F Kessler, 'Culpa in Contrahendo, Bargaining in Good Faith, and Freedom of Contract: A Comparative Study’ (1964) 77 Harvard Law Review 401. As for its reception in Spain, see Medina Alcoz (n 11).

43 Craig (n 25), 610-611.

44 Act No. 1/2001, of 20 July, on Waters (Official Journal No. 176, of 24 July) (Act No. 1/2001), art 105(3); Sánchez Morón (n 24), 587.

45 Judgments of the Spanish Supreme Court (Administrative Law Chamber) of 7 June 1999 (RJ 1999/4264); and of 23 December 2010 (RJ 2011/1033). 
legal situation created by the administrative act, because it was precarious from the outset. ${ }^{46}$

In the third category, in certain areas of administrative law, revocation is allowed in emergency situations, ${ }^{47}$ namely when new external circumstances arise, under which the right would have not been granted ex ante, either because the law would have prohibited it, or because the application would have been rejected on a discretional basis. Compensation is generally excluded here, ${ }^{48}$ normally by virtue of the fiction that the right was granted under a tacit rebus sic stantibus condition. ${ }^{49}$ Nevertheless, economic arguments must be of particular importance given that what it is at stake is whether the risk of possible emergency situations has to be taken either by the public administration or by the rights-holder.

Finally, a fourth category of cases is that of rectification or withdrawal of lawful and favourable acts as a consequence of a new administrative assessment of the relevant public interest needs. Under EU law, revocation of these administrative decisions is generally forbidden. ${ }^{5}$ Likewise, revocation is not allowed under Spanish law on a general basis, but only if expressly provided for by the law. ${ }^{51}$ Furthermore, when this is the case, compensation is definitely required by the courts..$^{2}$ The constitutional basis of compensation in these cases is not the principle of legal certainty, under which the frustration of legitimate expectations would give rise to compensation for damages, ${ }^{53}$ but rather the right to private property, because these cases of revocation are considered to be expropriations. ${ }^{54}$ Indeed, under Spanish public law, the prerogative of expropriation can be exercised to take, not only real property, but any kind of property right. Accordingly, general administrative law statutes regulate the expropriation of administrative rights conferred by authorisations, concessions, and waivers. ${ }^{55}$

\footnotetext{
46 F Velasco Caballero, Las cláusulas accesorias de acto administrativo (Tecnos 1996) (Velasco Caballero), 262.

47 Act No. 1/2001 (n 44), art 104.

48 Sánchez Morón (n 24), 587.

49 Velasco Caballero (n 46), 287-291.

50 Algera v Common Assembly (n 23). See Craig (n 25), 612-613, 636-639.

${ }^{51}$ Act No. 1/2001 (n 44), art 65(3) and Act No. 22/1988, of 28 July, on Coastline Protection (Official Journal No. 181, of 29 July), art 77.

52 Judgment of the Spanish Supreme Court (Administrative Law Chamber) of 18 March 1993 (RJ 1993/1773); and of 22 September 1999 (RJ 1999/6589).

53 Spanish Constitution (n 12), arts 9(3) and $106(2)$.

54 ibid, arts 33(1) and 33(3).

55 Act of 16 December 1954 (Official Journal No. 351, of 17 December), art 41.
} 
Interestingly enough, the fact that Spanish administrative law rationalises the right to be compensated within the conceptual and legal framework provided for by the law of expropriation, and not under the principle of legitimate expectations, confers a more robust protection upon the rights-holder. The reason is that the former guarantees the granting of complete compensation in the amount of both the actual damages and the loss of profit, whereas the latter only grants compensation for the negative interest, which excludes most future profits. ${ }^{56}$ In sum, legitimate expectations are better preserved outside the realm of the EU law principle that requires their protection. This also shows that Europeanisation of national administrative legal orders can lead to a lower level of protection of the interests that lie behind that principle.

\subsection{Departure from previous non-binding administrative action}

A third situation arises in cases of departure from individual representations,${ }^{57}$ and other forms of self-limitation of administrative authorities (Selbstbindung), namely frustration of non-binding promises, departure from the criteria expressed in answers previously given by the public administration to a question referred by an individual or firm, and violation of administrative precedents. All these situations have a common structure that brings them under the light of the principle of legitimate expectations, both in $\mathrm{EU}^{58}$ and in Spanish law. ${ }^{59}$

First, the previous administrative action gives rise to a legitimate expectation of future administrative behaviour of a particular individual or firm. It can be a promise made by the authority, an answer given in the context of a question referred by individuals or firms, or an administrative practice that has consistently been followed in the past. For a legitimate expectation to arise, what is relevant is not the subjective trust of the individual or firm, but rather the existence of objective criteria that could plausibly lead to such trust and reliance existing. ${ }^{60}$ Thus, the fact that the administrative precedent follows a criterion expressed in a soft law instrument might lead to this conclusion. Although it cannot be completely excluded, ${ }^{61}$ legitimate expectations only seldom arise from simple administrative inactivity, because these objective criteria normally require

\footnotetext{
Craig (n 43).

ibid 619-625.

Craig (n 25), 619-625.

Díez Sastre (n 6), 383 .

ibid 383-385.

Case 223/85 Rijn-Schelde-Verolme (RSV) Machinefabrieken en Scheepswerven NVv Commission [1987] ECR I-4617. Thomas (n 1), 54-55.
} 
external signs that be sufficiently conclusive, ${ }^{62}$ if not unconditional, consistent and precise information. ${ }^{6_{3}}$ Simple tolerance of the authorities with a manifestly illegal conduct would not give rise to protected legitmate expectations. ${ }^{64}$ Unlike EU law, where unlawful representations are not protected under any circumstance, ${ }^{65}$ Spanish law follows here the same criterion that applies to unlawful decisions: if the representation made to the individual was manifestly unlawful, it would not give rise to a legitimate expectation, while, if the illegality was not easy discernible, this is not excluded. Secondly, the previous action has no legally binding force vis-à-vis the administrative authority, whose subsequent action is not invalid simply because it disregards it. Otherwise, the principle of legality would provide for an action of annulment, and there would be no room left for the principle of legitimate expectations. ${ }^{66}$ Finally, subsequent action that deviates from the announced or implied administrative behaviour must actually frustrate these legitimate expectations. Again, this means that the individual or firm must have actually made some investment or otherwise shown through her conduct that she actually relied on the promised, announced or implied administrative behaviour. ${ }^{67}$

A good example of this can be found in the traditional case law of the Supreme Court on administrative consultations in the area of land development. Individuals and firms usually hold consultations with the municipal authorities before purchasing properties or investing in development projects, in order to learn the current legal status of the property or the way in which the authority will exercise its discretion in the future. Unlike what happens in other areas of law - such as tax law, the answers given to these consultations are not binding, so the municipal authority can disregard them if they were wrong, and even if it decides to use its discretion differently. In that case, a subsequent administrative act will not be illegal just because it does not follow them. ${ }^{68}$ However, if this happens, the individual or firm can claim compensation for damages

62 Díez Sastre (n 6), 384.

63 Cases T-273/o1 Innova Privat-Akademie v Commission [2003] ECR II-1093, para 26; and T290/97 Mehibas Dordtselaan v Commission [2000] ECR II-15, para 59; and T387/09 Applied Microengineering Ltd $v$ Commission EU:T:2012:501, para 61.

64 Judgment of the Spanish Supreme Court (Administrative Law Chamber) of 8 July 2002 (RJ 2002/7277).

65 Cases 5/82 Hauptzollamt Krefeld v Maizena GmbH [1982] ECR 4601, para 22; Case T-2/93 Societe Anonyme a Participation Ouvriere Compagnie Nationale Air France v Commission [1994] ECR II-323, para. 102. Thomas (n 1), 62; Craig (n 25), 639-641.

66 Medina Alcoz (n 11).

67 Díez Sastre (n 6), 385-386.

68 Judgments of the Spanish Supreme Court (Administrative Law Chamber) of 11 May 1978 (RJ 1978/2666); of 11 December 1978 (1978/4567); and of 10 April 2000 (RJ 2000/4931). 
directly caused by the response of the administrative authority. ${ }^{69}$ Compensation would only cover damages actually suffered by the claimant in view of the investments that she had made, but no loss of profit. In the words of the Supreme Court:

«Answers given to consultations on land development issues do not bind the municipality who has given them, so that the individual has no right to get a licence according to them, [nor can he seek] the annulment of the subsequent administrative decision that disregards their content. In spite of this, the individual does have a right to be compensated for the damages suffered because of them, such as the cost of the projects that might have been drafted following the consultation». ${ }^{70}$

This was already a well-established doctrine before the accession of Spain to the European Communities, and its content has remained untouched after the formal adoption of the principle of legitimate expectations in 1989 through case law, and in 1999 by the Administrative Procedure Act. In the past, it was based directly on the principle of extracontractual liability of administrative authorities. ${ }^{71}$ Interestingly enough, this has always led to the same outcome that should be implemented under the principle of legitimate expectations because, as has been said, the latter provides a legal basis for compensating the negative interest, excluding any loss of profit related to the future exercise of the right. ${ }^{72}$ In sum, Spanish administrative law had already provided for the same solution, which has not been influenced in any relevant respect by the formal incorporation of the EU law principle of legitimate expectations.

\subsection{Non-fiscal State aid recovery}

Finally, a remark must be made about a special case of withdrawal of unlawful, favourable administrative acts where the influence of EU law has been particularly acute - and not precisely in line with the protection of legitimate expectations. The enforcement of Commission Decisions declaring a subsidy granted by an administrative act to be incompatible with the internal

69 Judgments of the Spanish Supreme Court (Administrative Law Chamber) of 7 February 1978 (RJ 1978/582); of 3 July 1978 (RJ 1978/2835); and of 29 October 1980 (RJ 1980/3459).

70 Judgment of the Spanish Supreme Court (Administrative Law Chamber) of 30 July 1986 (RJ 1986/7053), para. 2. This is now explicitly established by Legislative Decree 7/2015, of 30 October 2015, on Land Law (Official Journal No. 261, of 31 October 2015, 103232-103290), art 13(2) a).

71 Spanish Constitution (n 12), art 33(3).

72 Craig (n 43). 
market has been always problematic in Spain. ${ }^{73}$ According to the general view, before ordering the recovery of the subsidy, the administrative act had to first be formally annulled by the administrative authority. And this was not easy because under Spanish administrative law, ${ }^{74}$ favourable administrative acts, such as those granting a subsidy and other State aid to an individual or firm, can only be withdrawn by the authority that adopted them if the ground of illegality was particularly serious and manifest, and after having implemented a particularly detailed administrative procedure.

These substantive and procedural conditions are aimed at protecting the stability of favourable administrative acts against an administrative declaration of invalidity, and therefore they protect the interest that lies behind the principle of legitimate expectations. But at the same time they have been hindering the effectiveness of Commission Decisions, and have been partly responsible for enforcement shortcomings. In this case, EU law did not promote, but rather opposed legal certainty, legitimate expectations and the protection of legal status quo. In order to comply with the primacy of Commission Decisions, national law on subsidies was modified to make it clear that State aid can be recovered following a Commission Decision whether or not the act granting State aid was being annulled. Since 2003, the Spanish Act on Subsidies states that:

'The amounts received will be reimbursed, together with the corresponding interest from the moment of the payment of the subsidy until the date on which the reimbursement is agreed, in the following cases: [...] h) The adoption of a recovery order according to the provisions of Articles 87 to 89 of the Treaty on European Union [current Articles 107 to 109 TFEU]'. ${ }^{75}$

Since then, Spanish courts have been able to apply this specific provision of domestic law in order to recover illegal State aid, particularly non-fiscal State aid granted by individual administrative acts. If there is a Commission Decision declaring the illegality of the subsidy, it is no longer required that the administrative act be annulled. This is an exception to the general rule provided for by our Administrative Procedure Act, ${ }^{76}$ and it is readily apparent that it does not contribute to a more robust protection of legitimate expectations.

73 See L Arroyo Jiménez and P Pérez Fernández, 'Private Enforcement in Spain' in W Wurmnest, F Wollenschläger and T Möllers (eds), Private Enforcement of European Competition and State Aid Law: Current Challenges and the Way Forward (Kluwer Law 2020) forthcoming.

74 See Section 3(1).

75 Act No. 38/2003, of 17 November, on Subsidies (Official Journal No. 276, of 18 November), art $37(1)$.

${ }^{6}$ Judgment of the Supreme Court (Administrative Law Division), of 5 April 2018 (RC $\left.3661 / 2015\right)$. 


\section{Legitimate expectations and legislative and administrative rules}

4.1. The old approach: a narrow interpretation of the non-retroactivity principle

Article 9.3 of the 1978 Spanish Constitution establishes the 'principle of non-retroactivity' of both 'non-favourable sanctioning provisions', and provisions 'restricting individual rights'. The first instance of this non-retroactivity principle is a fundamental piece of modern criminal law that has not raised many questions. The second one, by contrast, has given rise to a number of controversies, in that the meaning of the expressions 'retroactivity', 'rights', and 'individual' not being clear at all.

During its earliest years (1981-1987), the Spanish Constitutional Court interpreted the second instance in a very narrow sense. Firstly, the Court distinguished different degrees of retroactivity (maximum, medium, and minimum), and declared that only the maximum retroactivity was constitutionally forbidden. According to this interpretation, the prohibition of retroactivity would apply only to those events and legal effects that were already concluded when the new legislation entered into force. In turn, it would not apply to future legal effects of decisions made before the new legislation was passed. ${ }^{77}$ Secondly, the Constitutional Court declared that 'rights', in the sense of Article 9.3 of the Constitution, did not include 'mere legitimate expectations' (expectativas legítimas), nor 'eventual, conditioned or future rights', but only 'vested rights', namely rights that were already 'acquired and consolidated' before the new legislation was passed. ${ }^{78}$ Thirdly, the Court considered that the expression 'individual rights' covered only a few core human rights, namely those enshrined in Articles 15-29 of the Constitution, but not economic or social rights, provided for in Articles 30-52 - for example, the right to private property (Article 33), and the freedom to conduct a business (Article 38). ${ }^{79}$ This meant, for instance, that the resulting 'non-retroactivity principle' did not apply to economic regulation, nor to commercial and tax law. According to this early case law, it seemed that there were no constitutional limits to retrospective legislation in these and in other fields.

This interpretation was hard to accept, in particular after Spain joined the European Communities in 1986. Firstly, this was because retrospective legisla-

See, eg, Judgments of the Constitutional Court No. 27/1981, of 20 July; No. 42/1986, of 10 April (Judgment No. 42/1986); and No. 65/1987, of 21 May.

78

See, eg, Judgment of the Constitutional Court No. 99/1987, of 24 May.

79 See, eg, Judgment No. 42/1986 (n 78). 
tion might be extremely damaging in those fields, by substantially increasing the costs of and thereby adversely affecting investments, transactions and decisions made before that legislation had been passed. Secondly, in 1987 the European Court of Justice (as it was then known) had already delivered several judgments declaring that the application of retrospective rules in the abovementioned areas could violate Community law - in particular the general principles of legal certainty and legitimate expectations. ${ }^{80}$ Thirdly, at that time, the Constitutional and Supreme Courts of other European countries had also established a similar legal doctrine. Lastly, as we will see in the following, the principle of legal certainty was and still is enshrined in the Spanish Constitution of 1978.

\subsection{The new approach: legal certainty to limit retroactivity}

It is not sheer chance that the Spanish Constitutional Court adopted a new approach to the retroactivity issue in 1987. As paradoxical as it may sound, the Constitutional Court did so not by changing its previous construction of the 'principle of non-retroactivity', but by declaring that some retroactive rules, although not incompatible with this constitutional provision, might violate other constitutional principles and, in particular, that of legal certainty, which is also explicitly mentioned by Article 9.3 of the Constitution.

This legal doctrine was first established by Judgment No. 126/1987 of 16 July. ${ }^{81}$ The Constitutional Court reviewed a legislative rule that had increased the tax to be paid for some gambling activities carried out during the year before the rule was passed. The Court confirmed its previous case-law, by declaring that the 'principle of non-retroactivity' did not apply here, as tax rules were not provisions 'restricting individual rights' in the sense of Article 9.3 of the Constitution. However, the Court also stated that retroactive tax legislation might be unconstitutional if it violates other constitutional principles and, in particular, that of legal certainty. In order to justify this statement, the Constitutional Court - as well as the lower courts that had brought the case before it - explicitly invoked the case law made in similar cases by the Italian Corte Constituzionale, ${ }^{82}$

80 Cases 98/78 Firma A. Rackev Hauptzollamt Mainz [1979] ECR I-69; and 224/82 Meiko-Konservenfabrik [1983] ECR I-2539.

81 Nevertheless, this doctrine could already be found in the dissenting opinion of Judge R GómezFerrer to Judgment of the Constitutional Court No. 6/1983, of 4 February.

82 Judgments of the Constitutional Court No. 45/1964, 44/1966, 75/1969 and 54/1980. 
the German Bundesverfassungsgericht, ${ }^{83}$ and the Supreme Court of the United States. $^{84}$

This doctrine has been confirmed by a number of later judgments on retroactive legal changes concerning not only taxes, ${ }^{85}$ but also social security contributions, ${ }^{86}$ pension plans, ${ }^{87}$ performance assessment of civil servants, ${ }^{88}$ urban planning, ${ }^{89}$ State aid for investment in renewable energies ${ }^{90}$ or for housing,,$^{91}$ and economic regulation..$^{92}$ Ironically, the principle of legal certainty has actually become more relevant than the 'principle of non-retroactivity' in order to review whether retroactive legislation is unconstitutional or not.

It must be noted that this was not a "dynamic" legal transplant, but a "static" one. The Spanish Constitutional Court imported that foreign doctrine as it arguably was in 1987 but did not considered how it evolved afterwards. In fact, since then, the Spanish Court has only twice mentioned the case law of the abovementiond foreign Courts on this topic. And, in both occasions, it just quoted the same old decision of the German Bundesverfassungsgericht that it had already quoted in $1987 . .^{93}$

\subsection{The new approach: the balancing test}

In Judgment No. 126/1987, the Spanish Constitutional Court also pointed out that legal certainty did not imply an absolute prohibition on retroactive legislation, as that prohibition would 'freeze' the legal system and impede social progress. In order to determine whether the retroactive effects of a legal rule were compatible or not with that principle, a balancing test was

83 Judgment of 19 December 1961 (BVerfGE 13, 261). On the German case law on this topic at that time, see K Vogel, 'Rechtssicherheit und Rückwirkung zwischen Vernunftrecht und Verfassungsrecht' [1988] Juristen Zeitung 833.

84 United States v. Hudson, 299 U.S. 498 (1937); Welch v. Henry, 305 U.S. 134 (1938); and United States v. Darusmont, 449 U.S. 292 (1981).

85 Judgments of the Constitutional Court No. 182/1997, of 28 October (Judgment No. 182/1997); No. 150/1990; No. 173/1996, of 31 October (Judgment No. 173/1996); No. 273/2000, of 15 November (Judgment No. 273/2000); No. 231/2001; No. 116/2009, of 18 May (Judgment No. 116/2009); No. 176/2011, of 8 November; and No. 121/2016, of 23 June (Judgment No. 121/2016). Judgment of the Constitutional Court No. 89/2009, of 20 April (Judgment No. 89/2009).

Judgment of the Constitutional Court No. 90/2009, of 20 April.

8 Judgment of the Constitutional Court No. 26/2016, of 18 February.

89 Judgment of the Constitutional Court No. 141/2014, of 11 September.

$9 \circ$ Judgment of the Constitutional Court No. 270/2015, of 17 December (Judgment No. 270/2015).

91 Judgment of the Constitutional Court No. 51/2018, of 10 May (Judgment No. 51/2018).

92 Judgments of the Constitutional Court No. 332/2005, of 15 December and No. 112/2006, of 5 April.

93 Judgment No. 89/2009 (n 86) and Judgment No. 51/2018 (n 91). 
to be carried out, where several factors, in particular, the 'degree of retroactivity' of the considered legal rule, had to be taken into account.

The Spanish Constitutional Court explicitly embraced the distinction made by its German counterpart between 'actual' and 'apparent' retroactivity. ${ }^{94}$ In the former case, where a legal rule is applied to events that have already been concluded before it was passed (actual retroactivity), legal certainty will prevail prima facie, unless qualifying reasons of public interest justify such retroactive effects. In the latter case, where a rule produces legal effects with respect to events that have not been concluded yet (apparent retroactivity), protection of legal certainty is to be balanced with the relevant public interest in altering the law, with none of them prevailing prima facie over the other. In this particular case, the Court declared that the legislative provision at issue was not unconstitutional, taking into consideration the following: firstly, that the retrospective effects of the legislative provision at issue were limited to less than one year; and, secondly, that the legal change was necessary to ensure the principle of equality, namely to equate the tax burden on the concerned gambling activities with that imposed on similar gambling activities.

Subsequent judgments have refined this case-law and, in particular, the factors to be considered to strike a fair balance between legal certainty (namely the protection of legitimate expectations) and the public interests that require retroactivity. One of the most relevant factors in that regard is the foreseeability of the retrospective legal change. Legitimate expectations on the status quo not being retrospectively altered deserve protection if, and only if, such legal change was not foreseeable, meaning that it could not have been foreseen, from the point of view of a prudent and diligent agent (investor, trader, entrepreneur, taxpayer, and so on.). ${ }^{95}$

In order to determine whether the legal change at issue was foreseeable or not, several circumstances are to be taken into account. Firstly, the nature of the sector where retrospective legal changes take place. Changes will be more foreseeable: (i) the more intensely regulated the considered sector is; and (ii) the more frequently circumstances change in that sector, which in turn makes legal changes aimed at adapting the law to new circumstances more necessary and frequent..$^{6}$

\footnotetext{
94 As for the distinction in EU law, see Craig (n 25), 601-607.

95 See, eg, Judgment No. 270/2015 (n 90).

$9^{6}$ ibid.
} 
Secondly, the extent to which new legislation deviates from the apparent legal status quo is also relevant. If there is no deviation at all, because the new rule confirms that status quo, one can hardly accept that such rule was unforeseeable at the time it was passed. This is what usually happens in cases of legislative validations ('convalidaciones legislativas'), where the Spanish Parliament establishes a new law whose content reaffirms that of a previous (for example, administrative) rule that was illegal because of a mere formal or procedural defect. Under Spanish law, the previous rule enjoyed a presumption of validity, ${ }^{97}$ and, de facto, was apparently valid. Therefore, the new legislation that reiterates the old one is not unforeseeable, and it does not frustrate legitimate expectations if it retrospectively enters into force when the previous rule did so..$^{8}$

Another relevant factor is the amount of the costs derived from the retroactive rule for citizens and undertakings that relied on previous legislation. The magnitude of retrospective tax increases, for instance, has been a crucial factor when determining whether they were unconstitutional or not. ${ }^{99}$

Lastly, the Constitutional Court also considers to what extent specific public interests require the retroactive application of the rule at issue or, in other words, the magnitude of the social costs that non-retroactivity implies for those interests. For instance, in Judgment No. 270/2015 of 17 December, which upheld a substantial cutback in a very generous aid scheme established for investment in renewable energies, the Court took into account that such cutback was necessary to attain an overriding public interest ('perentorios $y$ superiores intereses públicos'). That scheme had given rise to a huge tariff deficit of the Spanish electricity system, which had become financially unsustainable, especially after the 2008 global economic crisis broke out.

One can see that this case-law is, in general terms, quite similar to that established on the same topic by other European courts, in particular the Court of Justice of the European Union ${ }^{100}$ and the German Bundesverfassungsgericht. ${ }^{101}$

97 For individual administrative decisions, see Act No. 39/2015 (n 18), art 39(1).

$9^{8}$ See, eg, Judgment No. $182 / 1997$ (n 85); and Judgment No. 273/2000 (n 85) However, Judgment No. 121/2016 (n 85), declared the retroactive validation of an administrative regulation whose 'nullity was foreseeable' to be unconstitutional; similarly, Judgment No. 116/2009 (n 85), quashed the retroactive validation of an administrative regulation that had already been annulled when the new law was passed.

99 See Judgment No. 173/1996 (n 85) which declared a legal provision retroactively increasing a tax by more than 200 percentage points as unconstitutional.

100 See, eg, J Raitio, 'Legal Certainty, Non-Retroactivity and Periods of Limitation in EU Law' (2008) 2 Legisprudence 9; Craig (n 25) 601-607.

101 See, eg, H Maurer, 'Kontinuitätsgewähr und Vertrauensschutz' in J Isensee and P Kirchhof (eds), Handbuch des Staatsrechts für die Bundesrepublik Deutschland (vol. III, 2nd edn, Müller 1996), 211-279. 
It has been noted, however, that the Spanish case law in this realm is less nuanced than those of its counterparts and, moreover, not always fully consistent with that of the Court of Justice, even where EU law applies. ${ }^{102}$ Specifically, the Constitutional Court does not implement the more or less clearly structured standard of review that can be found in the Court of Justice's case law. ${ }^{103}$ It is arguably still a work in progress.

\section{Legitimate expectations and State liability}

The Spanish Constitution explicitly provides that the government is liable, under certain circumstances, for damages caused either by the executive branch (Article 106.2) or by the judiciary (Article 121). It does not specifically refer to the scenario where damages result from legislative action or inaction. Nonetheless, the Spanish Supreme Court has declared that the Government might also be held liable for damages caused by the legislative branch, in two types of cases. Firstly, when the legislature has passed an unlawful provision, which violates either EU law or the Spanish Constitution. Secondly, when the legislature has established a provision that, albeit being lawful per se, imposes a 'special sacrifice', namely a 'disproportionate burden', upon some individuals.

\subsection{State liability for unlawful legislation}

Constitutional Court's Judgment No. 173/1996 quashed a 1990 law that had established a tax with retroactive effects, thereby violating the principle of legitimate expectations. At that time, it seemed that most of the people that had paid that tax were not going to recover it. Indeed, when that Judgment was published, (i) the five-years limitation period established for requesting the refund of overpaid taxes had already expired, and (ii) many courts and administrative authorities had enacted decisions declaring that such law was not unconstitutional and, therefore, the plaintiffs were not entitled to such refund. These decisions had become unappealable before the Constitutional Court's Judgment was published, and could not be reviewed anymore. Article 40.1 of the Organic Act 2/1979 of the Constitutional Court (Ley Orgánica del Tribunal Constitutional) establishes that judgments declaring the unconstitutionality of laws shall not provide grounds for review cases in which the uncon-

\footnotetext{
102 See JF Alenza García, 'Las energías renovables ante la fugacidad legislativa: la mitificación de los principios de (in)seguridad jurídica y de (des)confianza legítima’ (2016) 55 Actualidad Jurídica Ambiental, 3-22; Muñoz Machado (n 7); I Revuelta Pérez, 'Estándar del inversor prudente y confianza legítima’ (2019) 208 Revista de Administración Pública 403.

103 Craig (n 25), 603, 607.
} 
stitutional provisions were applied if these cases ended with unappealable judicial decisions, save criminal proceedings where a criminal or an administrative sanction was imposed if, as a consequence of the nullity of the unconstitutional law, the sanction would be reduced, limited or excluded. Moreover, under the case law of the Spanish Supreme Court, this rule also applies to cases concluded with administrative decisions, if they were not appealed within the statutory deadline.

Despite (or precisely because) of that, many taxpayers brought actions against the State for the damages they have suffered as a result of such unconstitutional law. Surprisingly enough, the Supreme Court upheld their claims, although they had gotten an unappealable decision rejecting the overpayment refund or not even applied for this refund within time. The Court argued that the action for damages was different from and did not depend on the action for refund. Affected taxpayers have one year, from the date the judgment annulling the unconstitutional provision was published, to file a claim for damages. ${ }^{104}$ Interestingly, the Supreme Court did not invoke the principle of legitimate expectations to justify this solution, although the unlawful legislation at issue had breached it.

This case law has been heavily criticized by several authors. ${ }^{105}$ It has been argued that such doctrine: (i) offsets, de facto, the effects of administrative and judicial decisions that are unappealable and to be preserved for the sake of legal certainty; (ii) contravenes the spirit of the abovementioned Article 40.1 of the Organic Law of the Constitutional Court; and (iii) gives the opportunity to obtain a legal remedy to individuals that did not avail themselves in due time of the legal remedies at their disposal.

The scope of this doctrine has been subsequently restricted. On the one hand, the Supreme Court declared that it did not applied to: (i) cases where the unconstitutional provision at issue was annulled by the Constitutional Court with prospective effects; ${ }^{106}$ nor to (ii) cases where the legislation was unlawful as a consequence of breaching EU law. This second rule, nonetheless, was re-

104 See, for instance, Judgments of the Supreme Court (Administrative Law Chamber) of 29 February 2000 (RC 49/1998); of 13 June 2000 (RC 567/1998); and of 15 July 2000 (RC 736/1997).

105 See G Doménech-Pascual, 'Responsabilidad patrimonial de la Administración por daños derivados de una ley inconstitucional' (2001) 110 Revista Española de Derecho Administrativo 275; E García de Enterría, 'Sobre la responsabilidad patrimonial del Estado como autor de una Ley declarada inconstitucional' (2005) 166 Revista de Administración Pública 99.

106 See G Doménech-Pascual, 'La responsabilidad patrimonial de la Administración por leyes declaradas inconstitucionales: las contradicciones del Tribunal Supremo’ (2005) 11 Impuestos 13. 
pealed after the European Court of Justice found that it was contrary to the principle of equivalence. ${ }^{107}$

On the other hand, Articles 32 and 34 of Act No 40/2015 have subjected that State liability to very strict conditions: firstly, claimants have to have previously exhausted every remedy against the decisions made in application of the unlawful legislation and, moreover, alleged that such legislation was unconstitutional or contrary to EU law; secondly, claimants can only be compensated for damages suffered within a period limitation of five years before the unlawful legislative provision was declared unconstitutional or contrary to EU law. In addition, when it comes to breaches of EU law, it is established that: (i) the rule of EU law infringed must be intended to confer rights on individuals; (ii) the infringement must be sufficiently serious; and (iii) there must be a direct link between the infringement and the damage sustained by the injured claimants. ${ }^{108}$

\subsection{State liability for lawful legislation}

The leading case on this issue was decided by the Supreme Court in its Judgment of 5 March $1993 .{ }^{109}$ The Spanish Parliament had passed a law providing for certain State aid - mostly tax exemptions - to be granted to fisheries that would make certain investments. As a result of the Kingdom of Spain joining the European Communities, by virtue of a previous decision of the Spanish legislature, that aid scheme had to end. The Supreme Court declared that the affected firms were entitled to be compensated for the special sacrifice they suffered as a consequence of that. ${ }^{110}$

Subsequent case-law consolidated this doctrine. The Judgment of 17 February 1998 was passed on a case where the Balearic Islands Parliament had changed the legal regime of some pieces of land in order to preserve them from urban development. ${ }^{111}$ The Balearic legislature repealed the legal rule allowing development of that land for environmental reasons, thereby causing substantial costs to its owners, some of them being on the verge of developing it, or who had even already started to do so. After the Constitutional Court declared that

107 See Case C-118/o8 Transportes Urbanos y Servicios Generales SALv. Administración del Estado EU:C:2010:39; C Plaza Martín, 'Member States Liability for Legislative Injustice' (2010) 3 Review of European Administrative Law 27.

108 See G Doménech-Pascual, 'La menguante responsabilidad patrimonial del Estado por leyes contrarias a Derecho' (2018) 31 Corts - Anuari de Dret Parlamentari 411.

109 Judgment of the Supreme Court (Administrative Law Chamber) of 5 March 1993 (RC 1318/1990).

110 See also Judgments of the Supreme Court (Administrative Law Chamber) of 27 June 1994 (RC 200 and 300/1988); of 16 September 1997 (RC 265/1988); and of 6 July 1999 (RC 308/1995).

111 Judgment of the Supreme Court (Administrative Law Chamber) of 17 February 1998 (RC 327/1993). 
such legal change was not unconstitutional, the affected owners filed a State liability claim, which the Supreme Court upheld. In its Judgment of 20 January $1999,{ }^{112}$ the Supreme Court resolved a similar case in the same way. The Parliament of Extremadura had changed the legal regime of some hunting grounds, making it virtually impossible for their owners to continue to make a profit from them. In its Judgment of 8 October $1998,{ }^{113}$ the Supreme Court considered a case where the Canary Islands Parliament had imposed a new fuel tax, which affected existing fuel stocks. Thereafter, the claimant, an oil company, was not able to raise the price of those stocks when it sold them, given that such price was set by the Government. As a result, it suffered a substantial loss, insofar as the sale price was lower than the sum of the purchase price and the new tax. The Supreme Court declared it was entitled to be compensated for that loss. ${ }^{114}$

In these and in other analogous cases, the Supreme Court has given three main reasons in order to justify State liability. Firstly, it refers to the so-called principle of 'responsibility of public authorities' ('principio de responsabilidad de los poderes públicos'), enshrined in Article 9.3 of the Constitution. It must be noted that, in Spanish, the term 'responsabilidad' is quite ambiguous, as it might mean 'liability', but also 'accountability' or 'responsibility'. Secondly, the Court has argued that, if not compensated, that special sacrifice would violate the principle of equality of citizens before charges levied by the State (Articles 14 and 31.1 of the Constitution). Thirdly, it has invoked the principle of legitimate expectations in order to support the right to compensation.

It must be noted, however, that the government has rarely been held liable for such lawful legislative acts. The Supreme Court has dismissed the vast majority of claims for damages caused by the legislative branch in cases regarding deregulation of burial services, ${ }^{115}$ regulation of professional services, ${ }^{116}$ damages caused to some professionals as a consequence of Spain entering the European Community, ${ }^{117}$ a ban on advertising visible from public roads, ${ }^{118}$ civil (RC 5350/1994).

(RC 5578/1992).

114 See also Judgment of the Supreme Court (Administrative Law Chamber) of 9 October 1998 (RC 5609/1992).

115 Judgment of the Supreme Court (Administrative Law Chamber) of 27 April 2002 (RC 501/1998).

116 Judgments of the Supreme Court (Administrative Law Chamber) of 5 December 2000 (RC 4335/1996); and 16 December 2008 (RC 453/2006).

117 Judgments of the Supreme Court (Administrative Law Chamber) of 13 February 1997 (RC 399/1995); and 18 September 1997 (RC 1818/1990).

118

Judgment of the Supreme Court (Administrative Law Chamber) of 8 April 1997 (RC 7504/1992). 
service reforms, ${ }^{119}$ damages caused to municipalities as a result of a local tax being abolished, ${ }^{120}$ a ban on smoking in enclosed public places, ${ }^{121}$ and more.

The Supreme Court is far from having a systematic doctrine in order to determine whether the State is liable or not for the legislature having placed a disproportionate burden upon some individuals. Nonetheless, one can notice that it has used, explicitly or implicitly, two main criteria with that regard. The first one is whether the legal change was foreseeable from the point of view of a prudent agent. The second one is the impact of the legal change on the rights and interests of the affected individuals. Here, the Supreme Court usually has taken into consideration, inter alia, whether the new legislation contained transition policies that mitigated its negative effects for the claimants.

This case law deserves to be remarked upon. Firstly, the legislative provisions that have been reviewed for arguably imposing a special sacrifice also had retroactive effect, insofar as they applied to decisions, such as investments and acquisitions, made before such provisions were passed. What made these 'State liability cases' different from the 'retroactivity cases' considered above was not the retroactive effects of a legal change, but the remedy the claimants sought and which the courts eventually granted: either compensation for the losses caused by that legal change or the annulment of the change. However, neither Spanish courts nor Spanish legal scholars have yet developed any systematic and consistent criteria in order to determine in which circumstances one remedy is preferable to the other.

Secondly, a legislative provision imposing a special sacrifice on particular individuals might well be deemed an expropriation, as it deprives those individuals from some rights - development rights, hunting rights, and so on - or legitimate interests. It must be noted that Spanish legislation defines 'expropriation' in a very broad sense, as a 'singular deprivation from private property, or other rights or legitimate interests'. ${ }^{122}$ And, needless to say, under Spanish law the State may only expropriate rights or legitimate interests if and only if the affected individuals are provided with fair compensation (Article 33.3 of the Constitution). However, neither the Spanish Constitutional Court nor the Supreme Court have considered those legal provisions as 'regulatory takings', unlike the United States Supreme Court which has done so in analogous cir-

119 Judgments of the Supreme Court (Administrative Law Chamber) of 5 Mars 1993 (RC 3319/1991); of 30 November 1993 (RC 2156/1991), and 18 October 1997 (RC 223/1995).

120 Judgment of the Supreme Court (Administrative Law Chamber) of 28 October 2009 (RC 755/2008).

121 Judgment of the Supreme Court (Administrative Law Chamber) of 29 April 2010 (RC 591/2008).

122 Act of 16 December 1954, on Expropriation, art 1.1. 
cumstances. ${ }^{123}$ Those cases have not been framed as 'expropriation' cases, but as 'liability' ones.

Thirdly, the Spanish Supreme Court invokes the principle of legitimate expectations, even noting its EU law source, with the aim to justify a remedy - State liability for lawful legislation - that can be found in the law of some of its Member States, but not in EU law itself. ${ }^{124}$ Indeed, in FIAMM the Court of Justice considered whether the European Community might be held liable for damages caused by its lawful conduct. ${ }^{125}$ After reviewing the principles of the non-contractual liability of the Community for damages caused by its institutions, the Court stated that:

'while comparative examination of the Member States' legal systems enabled the Court to [find the] convergence of those legal systems in the establishment of a principle of liability in the case of unlawful action or an unlawful omission of the authority, including of a legislative nature, that is in no way the position as regards the possible existence of a principle of liability in the case of a lawful act or omission of the public authorities, in particular where it is of a legislative nature'. ${ }^{126}$

Therefore, the Court of Justice concluded that:

'as Community law currently stands, no liability regime exists under which the Community can incur liability for conduct falling within the sphere of its legislative competence in a situation where any failure of such conduct to comply with the WTO agreements cannot be relied upon before the Community courts'. ${ }^{127}$

123 See, eg, WA Fishel, Regulatory takings (HUP 1995).

124 See the Opinion of Advocate General Maduro in cases C-120/06 P and C-120/o6 P, FIAMM and others $v$ Council and Commission [2008] (FIAMM), paras 62-63 and HJ Bronkhorst, 'The valid legislative act as a cause of liability of the Communities'in HG Chermers, T Heukels, and P Mead (eds), Non-contractual liability onf the European Communities (Martinus Nijhoff Publishers 1988), 13-22; E Engelhard and others, 'Let's Think Twice before We Revise! Égalité as the Foundation of Liability for Lawful Public Sector Acts' (2014) 10(3) Utrecht Law Review 55. See also the criticism from E García de Enterría, 'El principio de protección de la confianza legítima como supuesto título justificativo de la responsabilidad patrimonial del Estado Legislador' (2002) 159 Revista de Administración Pública 173.

125 See K Arend, 'EC Liability in the Absence of Unlawfulness' (2009) 1 Göttingen Journal of International Law 199; D Utrilla, 'La garantía patrimonial ante actos normativos lícitos en Derecho comunitario: entre la responsabilidad patrimonial objetiva y el derecho de propiedad' (2010) 181 Revista de Administración Pública 219.

126 FIAMM (n 124), para 175 .

127 FIAMM (n 124), para 176. 
In Holcim, ${ }^{128}$ the Court of Justice seemed to leave the door open to the possibility of the European Union being held liable for lawful acts, had they caused unusual and special damage. Nonetheless, it did not actually affirm that strict liability either. The Court of First Instance (the General Court), which does not close the door to that strict liability either, has defined special damage in, as that which:

'affects a particular class of economic operators in a disproportionate manner by comparison with other operators and unusual damage is that which exceeds the limits of the economic risks inherent in operating in the sector concerned, the legislative measure that gave rise to the damage pleaded not being justified by a general economic interest'. ${ }^{129}$

In sum, the EU law principle of legitimate expectations has been used by the Supreme Court in order to support a right to be compensated for damages caused by lawful parliamentary statutes. This doctrine is controversial in and of itself, since it might well be argued that a statute imposing a disproportionate burden on an individual or firm without providing for fair compensation violates the right to private property (Article 331.1) and the constitutional discipline of expropriation (Article 33.3). Moreover, it is questionable to invoke EU law for that purpose, when the existence of such a rule in that legal order has been expressly rejected by the Court of Justice.

\section{Conclusion}

It is now time to look back at the research questions of this article. On a general basis, we observe that the impact of the EU law principle of legitimate expectations on Spanish administrative law has not been uniform, but rather differs depending on the area of law. On the other hand, even where this principle was at stake, EU law has not always pushed towards a more robust protection of legitimate expectations or - more broadly - of stability of the legal status quo. Therefore, Europeanisation of Spanish administrative law through the principle of legitimate expectations has been variable and ambiguous. More specifically, the following claims can be made.

Firstly, the disparate impact of EU law on different areas of Spanish administrative law can be partially accounted for in view of whether they are subject or not to formal legislative codification. On the one hand, such an impact has

128 Case C-556/14 P Holcim v. European Commission EU:C:2016:207.

129 Case T-170/00 Förde-Reederei v Council and Commission [2002] ECR II-515, para 56. 
been low in those realms where there already was a pre-existing set of codified legislative rules. The most relevant instance is the revocation of favourable administrative acts. ${ }^{130}$ The formal adoption of the principle of legitimate expectations has not led to a significant transformation of the pre-existing law in this field, which already provided for a high degree of stability of the rights and interests granted by them. Nevertheless, some exceptions can also be observed. One is the case law that, under certain circumstances, qualifies revocation of unlawful and favourable acts by granting compensation to the affected individuals. Spanish courts are here applying criteria used by both the Court of Justice of the European Union and German courts in legitimate expectation-cases. Another exception is the legislative reform of recovery of subsidies, in order to make it unnecessary to previously withdraw the granting decision. ${ }^{131}$ The influence of EU law here has definitely not increased the degree of protection of legitimate expectations.

On the other hand, the impact of the EU law principle of legitimate expectations has been generally high where there was no such set of codified rules. The main examples are the constitutional limits to retroactivity of tax and economic legislation, as well as State liability for damages caused by lawful legislative provisions. In the first case, the Spanish Constitutional Court has imported a substantial part of the balancing approach used by the Court of Justice of the European Union and its counterparts of other Member States in order to review the retroactive effect of legal rules. ${ }^{132}$ In the second case, the Spanish Supreme Court has invoked the principle of legitimate expectations as one of the main arguments supporting the possibility of the government being held liable for its lawful legislation. ${ }^{133}$ Interestingly, in doing so, the Supreme Court has gone far beyond the case-law of the Court of Justice of the European Union, which has considered but not confirmed that strict liability yet, nor even examined the role that principle might play in that regard. Another relevant area of administrative law that has not been codified is that composed of situations of selflimitation of administrative authorities. This has traditionally been dealt with by Spanish courts. ${ }^{134}$ The EU law principle of legitimate expectations has not led to a significant evolution of the relevant case law. But this is probably due to the fact that the latter already protected legal certainty in a very similar vein - if not more generously. Hence, national administrative law was already aligned with EU law in terms of protection of legitimate expectations.

\footnotetext{
See Section 3(1).

See Section 3(4).

See Section $4(2)$ and $4(3)$.

See Section 5.

See Section 3(3).
} 
Secondly, another hypothesis of this article related to the role of the national Constitution as a competing driving force of administrative law, next to Europeanisation. Despite Spanish administrative law being highly constitutionalised, ${ }^{135}$ this has not affected the influence of the EU law principle of legitimate expectations. Hence, retroactivity of legislative and administrative rules is one of the areas where the Spanish Constitution most resolutely limits and steers administrative law, and also where EU law has given rise to a most prominent process of transformation. It can be plausibly argued that, in Spain, constitutionalisation has not been an obstacle for the influence of EU law on administrative legislation and case law. The reason might be the decisive openness towards external and comparative influences of the Constitution itself, as well as of public law doctrine created in its interpretation. ${ }^{136}$

A third suggested criterion pointed at how rigid or flexible both rule-making and judicial precedent are. Both administrative legislation and case law are quite flexible in Spain. And this has facilitated the incorporation of impulses coming from EU law. As for legislation, on the one hand, Act No. 4/1999 modified the 1992 Administrative Procedure Act in order to proclaim protection of legitimate expectations as a general principle of Spanish administrative law. ${ }^{137}$ Despite it pushing in the opposite direction, Act No. 38/2003 ended the need for a previous withdrawal of the granting administrative act, in order to facilitate the implementation of Commission Decisions ordering the recovery of State aid. ${ }^{138}$ On the other hand, the Supreme Court has been eager to modify its case law in order to implement the doctrine of the Court of Justice, especially when the latter was seen as being helpful from the perspective of its own agenda. Again, this has been the case of retroactive legislation, while in the area of rectification or withdrawal of administrative acts the Supreme Court has been more cautious.

Finally, the Spanish case law on the principle of legitimate expectations is arguably still a work in progress, for several reasons. Firstly, it is less systematic and nuanced than that developed with respect to similar problems in other European legal systems. Secondly, it is not always fully consistent with that of the Court of Justice, even where EU law applies. Thirdly, it has several loose ends that need tying up. There is a lack of, for instance, any criteria to determine

\footnotetext{
135 Arroyo Jiménez (n 19).

${ }_{136}$ A Gallego Anabitarte, 'La influencia extranjera en el Derecho Administrativo español desde 1950 a hoy' (1999) 150 Revista de Administración Pública 75; JA Santamaría Pastor, 'Spanien' in A von Bogdandy, S Cassese and PM Huber (eds), Handbuch Ius Publicum Europeum (vol IV, C.H.Beck 2011), 323-364.

137 See Section 2.

138 See Section 3(4).
} 
whether, why and when the retroactive effects of legislation are to be annulled, or they just need to be mitigated by means of compensation. Legal academics have not been very helpful in that regard. We have here a rather relevant theoretical job to be done. 